\title{
Az intellektuális tőke hatékonysága, mint meghatározó innovációs tényező
}

\section{The Efficiency of Intellectual Capital as a Crucial Factor of Innovation}

\author{
B. BÉRESNÉ MÁRTHA ${ }^{1}-$ V. LAKATOS² - G. TÖMÖRI ${ }^{3}$ \\ ${ }^{123}$ Debreceni Egyetem, Gazdaságtudományi Kar, Számviteli és Pénzügyi Intézet, Kontrolling Tanszék \\ beresne.martha.bernadett@econ.unideb.hu; lakatos.vilmos@econ.unideb.hu; \\ tomori.gergo@econ.undeb.hu
}

\begin{abstract}
Absztrakt. Napjaink világgazdaságában erőteljes elmozdulás érzékelhetô a termelő vállalatok felől a szolgáltatások irányába, amely mind a gazdaságpolitikai döntéshozókat, mind az üzleti vállalkozás érintettjeit, a tulajdonosokat, beszállítókat, versenytársakat, illetve a hétköznapi embereket, a fogyasztókat is kihívás elé állítja: a szerkezetváltás egyaránt ösztönöz minden gazdasági szereplőt arra, hogy megtanuljon alkalmazkodni az új tendenciákhoz. Kutatásunk fókuszában éppen ezért az innovációt és a vállalatok értékteremtố képességét állítottuk. Az IT szektor jelenleg az egyik leggyorsabban fejlődő és leginnovatívabb ágazatnak számít a szolgáltató iparágon belül. Az IT vállalatok sikerességét jelentős mértékben meghatározza az a képessége, hogy mennyire hatékonyan használják fel a rendelkezésükre álló immateriális javakat, azon belül is az intellektuális tőkét, amelyet viszont nem pénzügyi értékteremtő eszközként definiálunk. Felmerülhet tehát a kérdés: hogyan lehetséges számszerüsíteni, pénzben kifejezni a vizsgálni kívánt vállalatok intellektuális tőkéjét? A legsikeresebb magyar IT vállalatokra vonatkozóan éppen ezért kiszámítottuk a széles körben elismert mutatót, a VAICTM mutatót, melyre vonatkozóan hazai számítások még nem állnak rendelkezsére. Ez a mutató kiküszöböli a beszámolási sztenderdekből fakadó információhiányt azzal, hogy a módszertan a mindenki által hozzáférhetô, nyilvános pénzügyi beszámolók adatain alapul. Maga a mutató egy csúcsmutató, amelynek két fó részmutatója az intellektuális tőke hatékonyságát illetve a fizikai tôke hatékonyságát számszerúsíti.
\end{abstract}

Abstract. In today's global economy, there is a substantial shift from manufacturing to services, which challenges both economic policymakers, business stakeholders, owners, suppliers, competitors, and ordinary people: restructuring will encourage all economic players to learn how to adapt to new trends. That is why our research focuses on innovation and the ability of companies to create value. The IT sector is currently one of the fastest-growing and most innovative sectors within the service industry. The success of IT companies is greatly determined by their ability, how to make effective use of their intangible assets at their disposal, including intellectual capital, which is defined as a non-financial asset. So the question may arise: how is it possible to quantify and in monetary terms the intellectual capital of the companies to be examined? That is why, we calculated for the most successful Hungarian IT companies the widely recognized index, the VAICTM index, for which domestic calculations are not yet available. Indeed, this indicator eliminates the lack of information stemming from reporting standards by the methodology relying on publicly available financial 
reporting data. The indicator itself is a top indicator whose two main sub-indicators quantify the effectiveness of intellectual capital and physical capital.

\section{Bevezetés}

Napjaink világgazdaságában erőteljes elmozdulás érzékelhető a termelő vállalatok felől a szolgáltatások irányába. Az a nézet, miszerint az innováció, a folyamatos megújulás egyike - ha nem a legfontosabbika - a siker meghatározó tényezőinek, egyre általánosabbá válik. A vállalatok jelentős lépéselőnyre tehetnek szert, ha stratégiájukban alkalmazzák az innováció lehetséges formáit. Tudományos munkák, kutatások és természetesen a vállalatok által megtett út és saját tapasztalataik is rámutatnak arra, hogy a szolgáltató ágazat vállalatait nem feltétlenül kell a termelő vállalatokkal azonosan kezelni és elemezni, ugyanis a szolgáltatások saját jellemzőkkel, adottságokkal rendelkeznek, így fejlődési útjuk is eltérhet a termelő szektor vállalatainál tapasztaltaktól. Ugyanez az eszme hatotta át az innovációs kutatások eredményeit is, elfogadottá vált a szolgáltatás innováció fogalma, és 2005-ben, az Oslo Kézikönyv kiadásának időpontjában már maga az innováció fogalma is alkalmazkodott az új tendenciákhoz, kibővítették azt, így értelmezhetővé vált a szolgáltató szektor vállalataira is.

A világ tehát fejlődésben van. Azonban arra vonatkozóan, hogy hogyan mérhető egészen pontosan a szolgáltató szektor innovációs tevékenysége, még mindig nem született egy egységes statisztikai és mérési keretrendszer. Ennek egyik legfőbb oka, hogy a vállalatok kevés információt hoznak nyilvánosságra innovációs tevékenységüket illetően, és a jelenlegi pénzügyi beszámolókban foglaltak alapján nem tudunk pontos következtetéseket levonni az innovációs inputokra vonatkozóan $(3,13)$. Így azt, hogy egészen pontosan milyen hatása van a szolgáltató vállalatok innovációs tevékenységének azok pénzügyi mutatóira és eredményére, jelenlegi beszámolási standardok alapján kimutatni napjainkig kihívást jelent (4). Ezt a problémát felismerve azonban már az 1980-as évektől kezdve megindultak bizonyos kutatási projektek, amelyek hangsúlyozták, hogy a szolgáltató vállalatok sikerének a kulcsa a pénzügyi beszámolókban az immateriális javak között, azon belül is legfőképp a humán tőke kapcsán keresendő. Számos tanulmány, kötet és kutatás készült azzal a céllal, hogy ezen erőforrásokat még pontosabban tudjuk mérni, és segítséget nyújtsanak mind a vállalatvezetőknek abban, hogy sikeresebbé váljanak, mind pedig a befektetőknek abban, hogy teljesebb képet kapjanak a kiegészített beszámolókon keresztül az adott cégben rejlő növekedési potenciálról.

Van-e kapcsolat a szolgáltatás és a termelő tevékenység innovációja között, és ha igen, akkor abban milyen szerep vár a humánerőforrásra a jövőben? Az ipar 4.0 és 5.0 bevezetésével a gépesítés, a robotizmus növekedésének köszönhetően, valamilyen szinten csökkenni fog a gyártásban közvetlenül részt vevő munkaerő létszáma, hiszen a gépek képesek, sőt egyre inkább képessé válnak bizonyos munkafolyamatok átvételére, elvégzésére. Azonban a valóságos létszámcsökkenés helyett inkább a munka újrapozícionálásról érdemes beszélni. Az innovációnak köszönhetően az új technológiák sikeres bevezetésének garanciáját a munkavállalók kompetenciái, képességei, akaratereje, kreativitása kell, hogy jelentse. Oláh és szerzőtársai (5) szerint a vállalatok vezetői egyöntetűen egyetértenek abban, hogy a munkatársakkal szembeni minőségi elvárásokat az Ipar 4.0 és az Ipar 5.0 nagymértékben megváltoztatja. Az ilyen pozíciót 
betöltő munkatársak egyre nagyobb mértékben kapnak koordináló- és irányító szerepet. A teamekben való munka jelentősége a hálózatba kapcsolódás növekvő mértéke miatt is egyre nagyobb lesz. Az átalakulás sikeres kivitelezéséhez elengedhetetlen, hogy a vállalatok elegendő ráfordítást szánjanak kiváló IT infrastruktúrára és a munkavállalók megfelelő képességeinek a fejlesztésére, mint immateriális javak fejlesztésére. Az informatika kulcsfontosságú, a nem kielégítő IT- és információbiztonság a legveszélyesebb és ez jelenti a legnagyobb kockázatot az Ipar 5.0 területén (5). Éppen ezért a szolgáltató cégeknek olyan IT-biztonsági rendszereket kell kiépíteniük, melyek megfelelő védelmet biztosítnak a termelő cégek számára.

Tanulmányunk éppen ezért a szolgáltatások, az innováció és az értékteremtés hármasára fókuszál, melyet a legsikeresebb magyar információtechnológiai (IT) vállalatok példáján keresztül kívánunk bemutatni. Az IT vállalatok napjainkban köztudottan az egyik leggyorsabban fejlődő és leginnovatívabb ágazatnak számítanak a szolgáltató iparágon belül. Abban pedig, hogy melyik IT vállalatok tekinthetők a legsikeresebbeknek Magyarországon a HVG minden év őszén közzétett listája nyújtott segítséget, ahol az árbevétel és nyereségrekorderek, illetve a legnagyobb hozzáadott értéket felmutató vállalatok szerepelnek.

\section{Anyag és módszertan}

A vállalati értékteremtés szempontjából közelítve a vizsgált témát elmondható, hogy a pénzügyileg jól becsülhető tényezők helyett egyre jelentősebb szerep jut a humán erőforrásnak, a szervezeti struktúrának, a tanulásnak, így alapvetően az intellektuális tőkének. Az általunk fókuszba helyezett IT vállalatok is tipikusan ilyen, a humán tényezőtől nagyban függő vállalatok, így nagyon fontos, hogy a vállalat értékelésénél ezt a tényezőt is ugyanolyan körültekintően kezeljük, mint a termelő vállalatok esetében a fizikai eszközöket, hiszen az innovációt tulajdonképpen az alkalmazottak tudják megvalósítani. Az intellektuális tőke egyre inkább a vállalati versenyelőny egyik stratégiai eszközének számít (2), az információ-technológiai vállalatok esetében pedig a megfelelő szaktudással rendelkező és jó problémafelismerő munkavállalók pontosan ezen eszközök szerves részét képzik. Itt is felmerül azonban a kérdés, hogy hogyan mérhető az intellektuális tőke a rendelkezésre álló pénzügyi beszámolók alapján? A kérdésre választ adni, ahogy korábban rámutattunk, rendkívül nehéz, hiszen a humán tôkébe való befektetés sem jelenik meg közvetlenül a mérleg soraiban. A munkavállalóknak fizetett bér, az egyéb személyi jellegü ráfordítások, illetve az oktatás, amely során a munkavállalók fejlődhetnek, és új kompetenciákat sajátíthatnak el, mind ráfordításként jelenik meg az eredménykimutatásban (12) ahelyett, hogy azt a Chen és társai (2) által nevezett „stratégiai eszközként” könyvelnék el. Ennek azért is lenne nagy jelentősége, mert a személyi állomány, mint legjelentősebb értékteremtő eszköz egy IT vagy hasonlóan jelentős, de más szolgáltató szektorbeli vállalat számára, egyben olyan fontos erőforrás, amelytől függ a profit jövőbeli növekedése. Ahogy SveibyLloyd (12:1) fogalmaz: „Az oktatás az ember számára olyan, mint a gép számára a karbantartás. A toborzás pedig a befektetés megfelelője..."

Mindezen nehézségek ellenére, a humán tőke fontosságát felismerve már az 1980-as évektől kezdve megindult egyfajta törekvés ennek számba vételére (8). Jelen tanulmányban azt a módszert kívánjuk alkalmazni, amelynek szerzője Ante Pulic, és a köztudatban VAICтм („Value 
Added Intellectual Coefficient") módszer, mutató néven vált népszerűvé 1998-ban. Ez a módszer, ahogy azt a módszertan ismertetésénél a későbbiekben kifejtjük alkalmas arra, hogy mérje a humán tőke és a szervezeti tőke, összefoglaló nevén az intellektuális tőke nagyságát, annak hozzáadott értékét a vállalati értékteremtésen belül. Maga a módszer kutatók által széles körben elismert, de ugyanakkor bírált módszert is. Kritikái ellenére (10) az eljárás létjogosultságát alátámasztja, hogy számos tanulmányban alkalmazták ezt a módszert: vizsgálták vele többek között az intellektuális tőke hatását a lengyel, a malajziai és az indonéz bankszektor piaci értékére, az iráni gyógyszeriparra, a brazil textiliparra. Több olaszországi cégeken folytattak vizsgálatot arra tekintettel, hogy az intellektuális tőke komponensei (humán-, szervezeti,- és kapcsolati tőke) tudnak-e vállalati értéket teremteni $(1 ; 6 ; 9 ; 14 ; 15)$. Mindezen tanulmányok rámutattak, hogy a humán tőke hatékonyságának közvetett szerepe van az intellektuális tőke és a piaci érték közötti kapcsolatban. Magyarországi IT vállalatokra vonatkozóan ilyen jellegű tudományos értekezéssel nem találkoztunk.

A vállalat számára értékteremtő erőforrás a „felhasznált tőke” (Capital employed, CE) illetve az intellektuális tőke (Intellectual Capital, IC). Előbbi két részből áll, a fizikai tőkéből (physical capital) és a pénzeszközökhöz kapcsolódó tőkéből (financial capital), utóbbi pedig a humán tőkéből és a szerkezeti (strukturális) tőkéből (11). A VAICтм felépítését, az alkalmazott mutatókat az 1. ábra ismerteti.

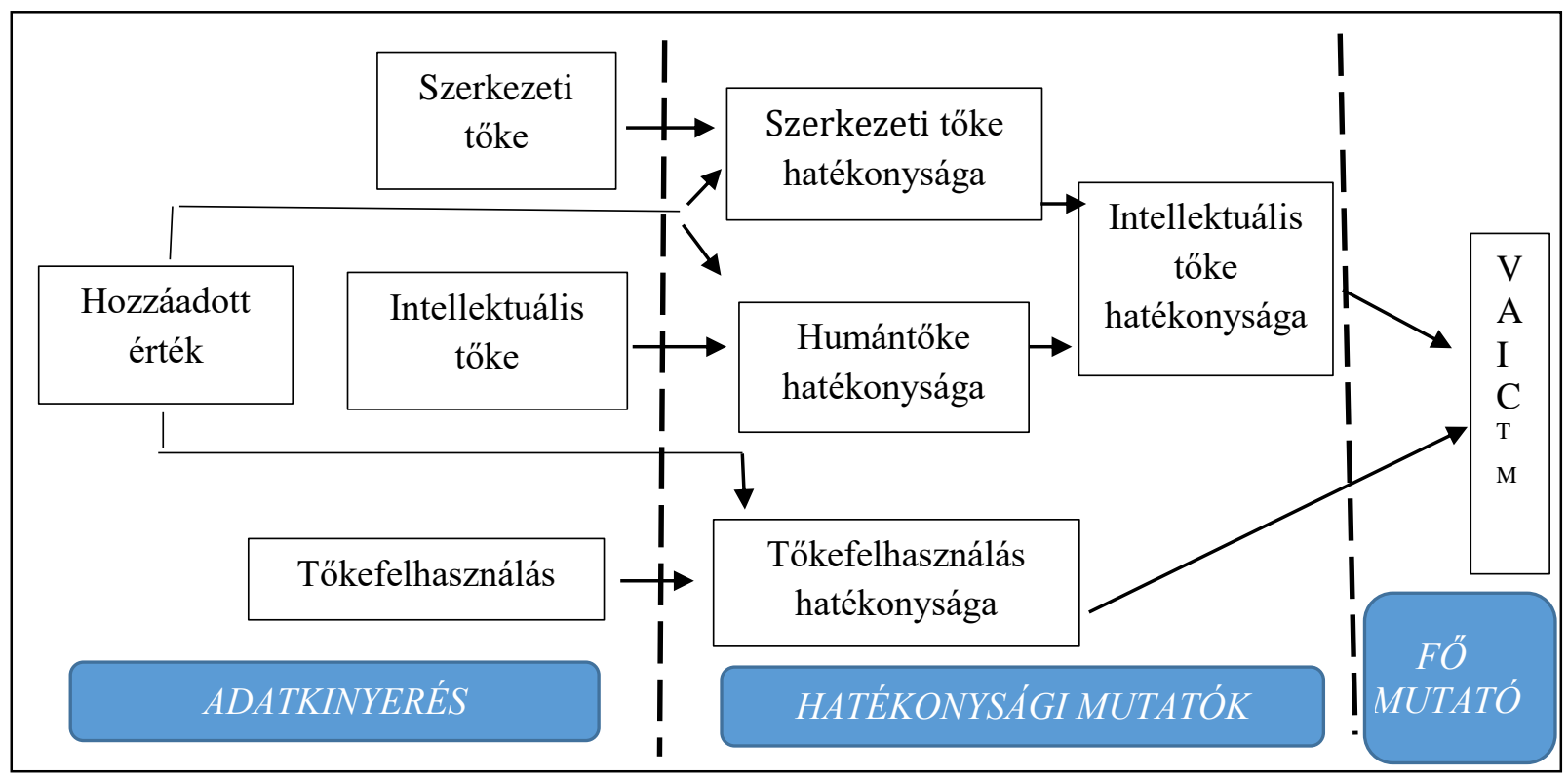

1. ábra. A VAIC ${ }^{T M}$ mutató felépítése

Forrás: (7) alapján, saját szerkesztés

Az adatok kinyerését illetően nyilvános adatok alapján számolhatók a mutatók, ugyanis bárki számára elérhetők a nyilvánosan közzétett éves pénzügyi beszámolókon keresztül, ezért könnyen össze lehet gyűjteni a számítás alapjául szolgáló információkat, mely a módszer egyik nagy előnyének számít. A standardizált módszer alapján lehetőség nyílik az összehasonlíthatóságra, hiszen hatékonysági mutatókat számol, amelyek közérthetőbbek, mint a hagyományos számviteli adatok, így a tulajdonosok és más érintettek számára is releváns információval szolgál. A fó mutató pedig a három hatékonysági mutató összegéből határozza meg az intellektuális tőke hozzáadott értékét. A VAIC ${ }^{\text {TM }}$ egyes komponensei a nemzetközi számviteli sztenderdeknek 
megfelelően vannak definiálva, ezért ahhoz, hogy a magyar beszámoló rendszerre vonatkozva tudjuk használni, szükséges volt azokat megfelelteti a hazi gyakorlatnak megfelelően. Az 1. táblázat mutatja be az egyes részmutatók meghatározásához szükséges számítási módokat, kapcsolódásokat, valamint az alapul szolgáló összetevőket.

\begin{tabular}{|c|c|c|}
\hline Név & Számítás & Megjegyzések \\
\hline Hozzáadott érték (VA) & $\mathrm{VA}=\mathrm{OP}+\mathrm{EC}+\mathrm{D}$ & $\begin{array}{c}\text { OP= Müködési költségek (ÜTE) } \\
\mathrm{EC}=\text { Munkavállalók költsége (Személyi } \\
\text { jellegű ráfordítások) } \\
\mathrm{D}=\text { Amortizáció }\end{array}$ \\
\hline $\begin{array}{c}\text { Tőkefelhasználás } \\
\text { hatékonysága (CEE) }\end{array}$ & $\mathrm{VA} / \mathrm{CE}$ & $\mathrm{CE}=$ nettó eszközérték (mérlegfőösszeg) \\
\hline $\begin{array}{c}\text { Humán tőke hatékonysága } \\
\text { (HCE) }\end{array}$ & $\mathrm{VA} / \mathrm{HC}$ & $\mathrm{HC}=$ Bérköltségek és bérjárulékok \\
\hline $\begin{array}{c}\text { Szerkezeti tőke } \\
\text { hatékonysága (SCE) }\end{array}$ & $\mathrm{SC} / \mathrm{VA}$ & $\begin{array}{c}\mathrm{SC}=\text { szerkezeti tőke, } \\
\mathrm{SC}=\mathrm{VA}-\mathrm{HC}\end{array}$ \\
\hline $\begin{array}{c}\text { Intellektuális tőke } \\
\text { hatékonysága (ICE) }\end{array}$ & $\mathrm{HCE}+\mathrm{SCE}$ & - \\
\hline
\end{tabular}

1. táblázat. VAIC ${ }^{T M}$ mutató összetevőinek meghatározása

Forrás: (8)

Összességében látható, hogy a VAICTM mutató a tőkefelhasználás hatékonyságának és az intellektuális tőke hatékonyságának egy aggregált mutatója, azaz képes mérni a vállalat erőforrás felhasználásának hatékonyságát a „kézzelfogható” és a „kézzel foghatatlan” eszközök tekintetében. A magasabb VAIC ${ }^{\mathrm{TM}}$ mutató magasabb értékteremtési lehetőséget jelez.

\section{Eredmények értékelése}

Alapvető célunk, hogy számszerűsíteni tudjuk azt az input mennyiséget, amely hozzájárulhat az IT vállalatok minél nagyobb értékteremtési képességéhez. Kutatásunk fókusza, hogy 2012-2017 közötti időszakban idősorosan meghatározzuk azon magyarországi IT vállalatok VAICTM mutatójának az értékét, melyek a vizsgált időintervalumon belül legalább egy alkalommal a TOP 500 (árbevétel, nyereség alapján) cégek között szerepeltek.

Feltételeztük, hogy a vállalati méret alapján lévő kisebb cégeknek magasabb VAICTM éréket kell produkálniuk ahhoz, hogy a piaci versenyben fel tudják venni a lépést a nagyobb vállalatokkal, és ezáltal helyt tudjanak állni.

Továbbá két kérdésre kerestünk választ:

1) Elmondható-e, hogy a VAIC ${ }^{\mathrm{TM}}$ adatok alakulását az iparági növekedés miatt szintén növekedő trend jellemzi?

2) A VAICTM értékek vajon magyarázhatóak-e a vállalati főtevékenységgel?

A legsikeresebb magyar információ-technológiai (IT) vállalatok kigyűjtéséhez az európai Creditreform Kft. céginformáció-szolgáltató magyarországi vállalata által összeállított, és a HVG gazdasági hetilapban minden év őszén közzétett Top500 listákat vettük alapul. Ez egyrészt az előző évi árbevétel, másrészt az adózott eredmény nagysága alapján rangsorolja a hazai vállalatokat. Célunk volt egy minél frissebb adatokon alapuló elemzés kivitelezése, ezért a munka 
kezdetekor utoljára rendelkezésre álló, azaz 2018 novemberében közzétett listák alapján készítettük el mintánkat. Ehhez a listából kiválasztottuk az „informatika” ágazathoz tartozó cégeket. Az elemzett listát úgy állítottuk össze, hogy 2012-2017 között a TOP 500 árbevétel és nyereség listán szereplő összes informatikai céget kigyűjtöttük, függetlenül attól, hogy nem minden évben szerepeltek a listán. Aki már egyszer bekerült a TOP listába, azt a céget elemeztük nemcsak a bekerülés évében, hanem visszamenőleg is. Így első körben 23 cég került a mintába. Ebből kettő cég már az elején kiesett. A Hungarian Innovation Systems Kft. (melynek egyetlen, 100\%-os szavazati aránnyal rendelkező részvényese az Amdocs Software Megoldások Kft.) nem rendelkezett alkalmazottakkal a vizsgált időintervallumban, ezért „Személyi jellegű ráfordításai” rendre 0 értékkel kerültek a képletekbe, amely viszont nem értelmezhető végső értékeket produkált. Hasonló helyzetben volt a 2017. júliusában alakult Great System Szoftverfejlesztő Kft., aki az alakulást követő évben már nulla alkalmazottal rendelkezett. Ennek okán ezt a két vállalatot már az elemzés elején kivettük a mintából, így 21 vállalat maradt. Ezen vállalatokat elsőként méret szerint csoportosítottuk, majd meghatároztuk a fő tevékenységi körüket, és végül az éves beszámoló adatait felhasználva az intellektuális tőke hozzáadott érékeinek együtthatóját kiszámoltuk. A vállalkozások méretét a kkv-król szóló törvény (2004. évi XXXIV. törvény a kis-és közép-vállalkozásokról, fejlődésük támogatásáról) és az EU vonatkozó ajánlásának (2003/361/EK) megfelelően két (illetve szükség esetén három) kritérium, a foglalkoztatottak száma és a nettó árbevétel, valamint a mérlegföösszeg segítségével soroltuk be. Az IT iparág növekedését tükrözi a 2. táblázat, miszerint 2012-ről 2017-re mintegy +40\%-kal nőtt meg azon vállalkozások száma, akik a vizsgált iparágban tevékenykednek, és piacvezetőnek számítanak.

\begin{tabular}{|l|c|c|c|}
\hline \multicolumn{1}{|c|}{ Vállalkozási méret } & 2012. & 2017. & Változás (\%) \\
\hline Nagyvállalat $(\mathrm{db})$ & 5 & 11 & 220 \\
\hline Közepes vállalat $(\mathrm{db})$ & 8 & 7 & 87,5 \\
\hline Kis vállalat $(\mathrm{db})$ & 1 & 2 & 200 \\
\hline Mikro vállalat $(\mathrm{db})$ & 1 & 1 & 100 \\
\hline Összesen $(\mathrm{db})$ & 15 & 21 & 140 \\
\hline
\end{tabular}

2. táblázat. Vállalkozások száma, változása méretkategóriáknak megfelelôen

Forrás: Éves beszámolók alapján saját számítás

Azon kérdésünkre, hogy a A VAICTM értékek vajon magyarázhatóak-e a vállalati főtevékenységgel, a 3. táblázat ad választ. A táblázatban található nulla értékű VAIC ТМ adatok több okból eredhetnek: volt olyan eset, amikor a vizsgált évben az adott cég még nem létezett, vagy létezett, de személyi jellegű ráfordítása nem volt, vagy éppen volt, csak a bérköltségek és járulékok bontását nem lehetett megállapítani, ezáltal a VAIC ${ }^{\text {тм }}$ mutató értékét sem lehetett meghatározni. Olyan eset is előfordult, amikor azért kapott egy vállalat nulla értéket, mert éppen negatív értékei voltak (pl. negatív ÜTE), vagy éppen kiugróan magas értéket produkált (pl. magas hozzáadott érték előállítás minimális személyi jellegű ráfodítással). (A méretkategóriák elkülönítése érdekében a nagy vállalatok VAICTM mutatójának az értékét félkövér számmal, a közepes méretűekét dőlt, míg a kis méretű cégket normál számmal jelöltük. A mikro vállalkozások jelölésére az aláhúzást alakalmaztuk.) 


\begin{tabular}{|c|c|c|c|c|}
\hline Vállalatok & 2012. & 2014. & 2015. & 2017. \\
\hline \multicolumn{5}{|c|}{ 6209. Egyéb információ-technológiai szolgáltatás } \\
\hline T-Systems Magyarország Zrt. & 1,90 & 2,12 & 1,79 & 2,20 \\
\hline IT Services Hungary Kft. & 3,48 & 3,66 & 3,68 & 3,32 \\
\hline $\begin{array}{l}\text { NISZ Nemzeti Kommunikációs Zrt. * (nem } \\
\text { konszolidált adat) }\end{array}$ & 0,00 & 3,21 & 2,32 & 2,43 \\
\hline IBM Magyarország Kft. & 3,02 & 3,13 & 3,23 & 2,64 \\
\hline BBox Solutions Kft. & 0,00 & 0,00 & $\underline{9,58}$ & $\underline{9,63}$ \\
\hline Euronet Banktechnikai Kft. & 1,41 & 8,65 & 15,43 & 20,35 \\
\hline Átlag VAIC'M & 2,45 & 4,15 & 6,01 & 6,76 \\
\hline \multicolumn{5}{|c|}{ 4651. Számítógép, periféria, szoftver nagykereskedelme } \\
\hline NNG Szoftverfejlesztő és Kereskedelmi Kft. & 3,62 & 3,99 & 4,10 & 4,45 \\
\hline \multicolumn{5}{|c|}{ 5829. Egyéb szoftverkiadás } \\
\hline SAP Hungary Kft. & 2,39 & 2,72 & 2,76 & 2,41 \\
\hline Amdocs Kft. & 0,00 & 0,00 & 0,00 & 18,96 \\
\hline i-Cell Mobilsoft Zrt. & 0,00 & 10,79 & 8,81 & 7,98 \\
\hline i-Cell Informatikai Fejlesztő Kft. & $\underline{2,93}$ & 7,07 & 6,62 & 3,07 \\
\hline AR-IP Szoftver-és Hardverfejlesztő Kft. & 0,00 & 6,24 & 10,06 & 7,45 \\
\hline Átlag VAIC & 2,66 & 6,71 & 7,06 & 7,97 \\
\hline \multicolumn{5}{|c|}{ 6201. Számítógépes programozás } \\
\hline Evosoft Hungary Kft. & 3,54 & 4,04 & 4,51 & 4,08 \\
\hline Epam Systems Kft. & 4,07 & 3,60 & 3,48 & 3,56 \\
\hline Expert Zrt. & 3,44 & 4,33 & 3,62 & 3,71 \\
\hline Átlag VAICTM & 3,68 & 3,99 & 3,87 & 3,78 \\
\hline \multicolumn{5}{|c|}{ 6202. Információ-technológiai szaktanácsadás } \\
\hline Graphisoft SE Zrt. & 4,16 & 3,96 & 3,97 & 4,95 \\
\hline Microsoft Magyarország Kft. & 2,06 & 2,36 & 3,07 & 3,30 \\
\hline Xapt Hungary Szoftver Kft. & 4,53 & 5,39 & 5,38 & 1,78 \\
\hline Átlag VAICTM & 3,58 & 3,90 & 4,14 & 3,34 \\
\hline \multicolumn{5}{|c|}{ 6311. Adatfeldolgozás, web-hosting szolgáltatás } \\
\hline IBM ISC Hungary Kft. & 4,48 & 6,27 & 2,35 & 4,90 \\
\hline \multicolumn{5}{|c|}{ 6312.Világháló-portál szolgáltatás } \\
\hline Profession.hu Kft. & 0,00 & 0,00 & 5,49 & 7,37 \\
\hline \multicolumn{5}{|c|}{ 6399. M. n. s. egyéb információs szolgáltatás } \\
\hline Microsec Zrt. & 3,38 & 4,36 & 2,99 & 2,74 \\
\hline
\end{tabular}

3. táblázat. IT vállalatok VAIC ${ }^{T M}$ mutatóinak értékei TEÁOR kódok szerinti bontásban

Forrás: Éves beszámoló adataiból saját számítás

Összesen nyolc TEÁOR kód alatt végezték a vizsgált cégek a tevékenységüket, ezek közül hármat emelnénk ki. A 6312. Világháló-porta szolgáltatást végző profession.hu céget, melyet 2014. végén alapítottak. Kis vállalkozásból hamar közepes válallkozássá nőtte ki magát. A humán tőkéjének a hatékonysága a 2015-ös évben már a vizsgált 21 vállalat közül a 6. helyen állt, míg 2017-re követve a piac fejlődését továbbra is a 6. helyet tartani tudta. Intellektulális tőke hatékonyságának együtthatója ezzel elérte a 7,37-es értéket. Az 5829-es egyéb szoftverkiadás főtevékenységi kód alá tartozó cégek átlagos VAICTM mutatójának az idősoros növekedése kiemelkedő, ugyanis majdnem megháromszorozták azt az oda tartozó vállalatok. Szintén hasonló, kiemelendő változáson mentek át a 6209. (egyéb információs-technológia szolgáltatás) kódú vállalatok átlagmutatója, habár értéke valamivel kisebb volt $(6,76)$. Alalpvetően kijelenthető, hogy nem 
feltétlenül a főtevékenység befolyásolj a mutató magas értékét, ugyanis a főtevékenységetől függeltenül a nagy cégek VAIC ${ }^{\text {TM }}$ mutatói jelentősen nem változtak. De azt azért ki kell elemnünk, hogy a magas humántőke hatékonyságot mutató cégek, akiknél egységnyi humánerőforrás költségre jutó hozzáadott érték magas, azoknak a cégenek kiemelkedően magas a VAICTM mutatója. Ami befolyásolja még a mutató értékét az inkább a méretkategória megugrása, átkerülés egy nagyobb vállalalti méretkagetóriába (ami történhet az árbevétel növelésével, a foglalkoztatottak számának növelése által vagy éppen a mérlegföösszeg emelkedésével).

Az iparágba tartozó piacvezető vállalkozások számának növekedésével a vizsgált időintervallum alatt látható (2. ábra), hogy az adott vállalati méretkategóriába tartozó cégek VAIC ${ }^{\mathrm{TM}}$ mutatónak az értékei is nőttek. Feltevésünk, miszerint a kisebb cégeknek magasabb főmutató értéket kell produkálniuk a piaci versenybe való belépéshez, és aztán a bennmaradáshoz, beigazolódott. Míg a nagy válallkozások esetében szinte stagnálás látható, addig a közepes-, kis- és mikro vállalatok esetében pedig tendenciáját tekintve növekedést tapasztalunk. Mivel csak 5 évre visszamenőleg elemeztük ezen cégek mutatóinak a változását, ezért mélyebb következtetést nem vonhatunk le, azonban a tendenciát jelzik.

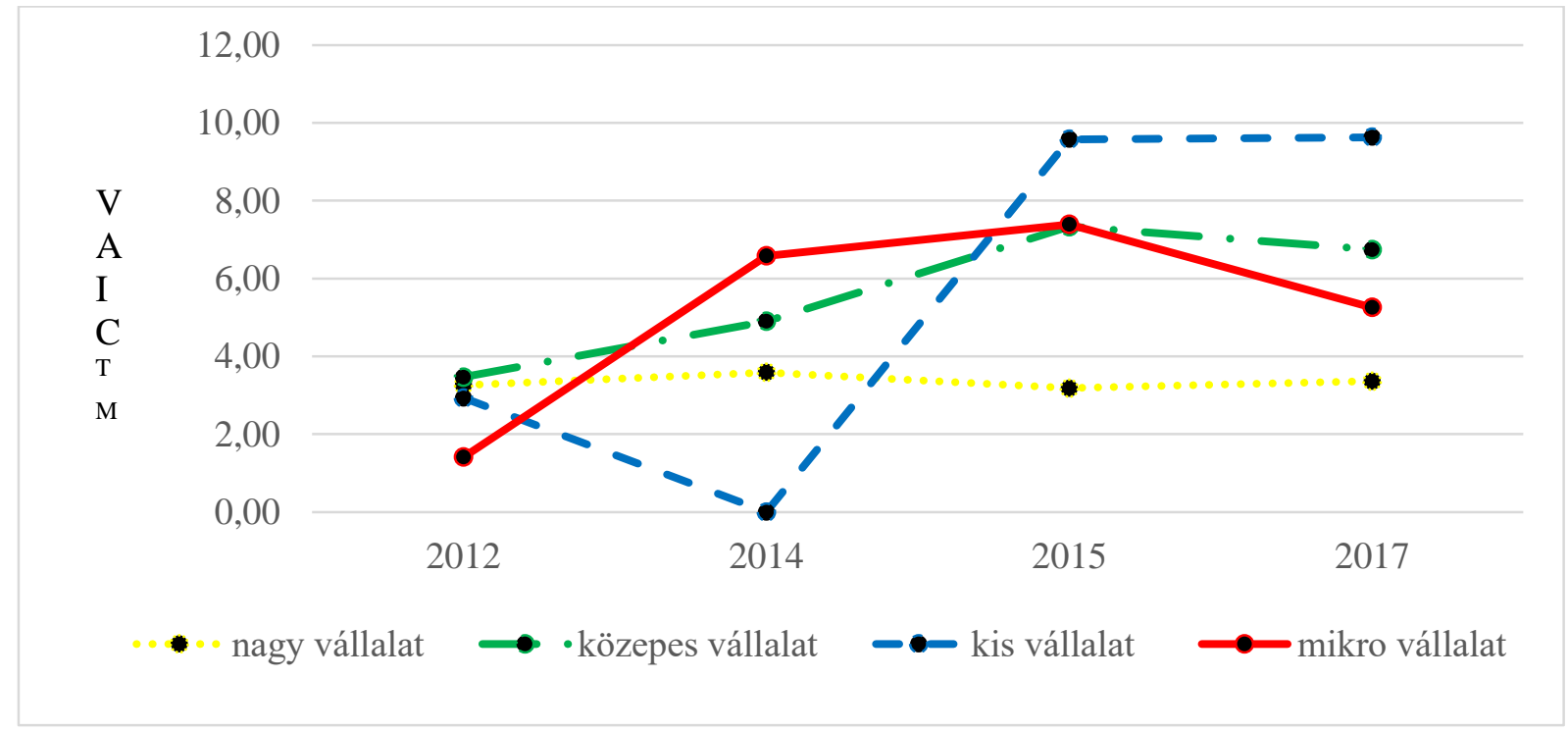

2. ábra: A vizsgált cégek VAICTM mutatóinak értéke vállalati méretkategória szerinti bontásban

Forrás: Éves beszámoló adatai alapján saját számítás

Mivel a VAICTM mutató additív elven számítandó, ezért a mutató magasabb értékei hatékonyabb vállalati működést jelezek. A hagyományos hatékonysági mutatókhoz képest eltérés azonban, hogy a mutatóban dominánsan van jelen az emberi erőforrás, mint értékképző tényező. A modell logikájából fakadóan a mutató magasabb pontszámmal jutalmazza azokat a vállalatokat, melyek alacsonyabb tőkeállománnyal magasabb hozzáadott értéket produkálnak, vagy éppen alacsonyabb bérköltséggel magas hozzáadott értéket teremtenek. A módszer gyengesége között meg kell említeni továbbá, hogy a hozzáadott érték kiszámítása során figyelembe veszi az amortizációt. Ebből kifolyólag azoknak a vállalatoknak a VAIC ${ }^{\text {тм }}$ mutatója ceteris paribus magasabb lesz, melyek tőkeintenzív stratégiát folytatnak, vagy magas leírási kulcsot használnak. 
Ennek oka abban keresendő, hogy mind a HCE (humántőke hatékonyság), mind a CEE (tőkefelhasználás hatékonysága) tag tartalmazza az amortizáció értékét.

\section{Következtetések}

Az intellektuális tôke gyakran rejtett vagyonként van jelen a szervezetek életében, és éppen ezért nem veszik figyelembe a pénzügyi beszámolókban és a számviteli rendszerekben. Az immateriális javak meglétét a befektetők egyre inkább elismerik, fókuszuk középpontjába helyezik vállalati és részvényesi stratégiai döntéseik során. Ennek ellenére az intellektuális tőke méréséhez továbbra sem létezik gyakorlatokkal alátámasztott világos iránymutatásokat tartalmazó módszer.

A VAIC ${ }^{\mathrm{TM}}$ módszer megkönnyíti az intellektuális tőke mérését és az egyes komponensek hatékonyságát, ezáltal lehetővé teszi a pontos irányítást és beavatkozást a leghatékonyabb üzleti területeken. Maga a módszer egy objektív módszernek tekinthető, mivel a szükséges számításhoz felhasznált adatok közvetlenül az éves beszámolókból származnak, amely lehetővé teszi a vállalatok összehasonlítását. Ez egy átlátható módszer, amely egyszerű és könnyen használható.

Megállapítottuk, hogy a vizsgált IT vállalatok esetében a VAICTM adatok alakulását az iparági növekedés miatt összességében szintén növekvő trend jellemzi.

Feltevésünk, miszerint a vállalati méret alajpán lévő kisebb cégeknek magasabb VAICTM éréket kell produkálniuk ahhoz, hogy a piaci versenyben fel tudják venni a lépést a nagyobb vállalatokkal, a vizsgált időintervallumon belül összességében bebizonyosodott.

Arra a kérdésünkre, miszerint a VAIC ${ }^{\text {TM }}$ értékek magyarázhatóak-e a vállalati főtevékenységgel, elvetésre került. Nem jelenthető ki egyértelműen, hogy az intellekutális tőke hozzáaadott értékének együtthatója magasabb lesz csupán csak egy bizonyos TEÁOR kód alá tartozó tevékenység végzése esetén. Saját elemzéseink alapján megállapítható, hogy azok a vállalatok rendelkeztek az átlaghoz képest magasabb VAICTM értékkel, melyek nagyon alacsony bér jellegü ráfordítással múködtek. A mutató „bünteti” azokat a vállalatokat, melyek ugyanakkora hozzáadott értéket termeltek, viszont kisebb strukturális tőkével és magasabb humán tőkével rendelkeztek.

Úgy gondoljuk, hogy néhány korlátozás ellenére a VAICTM sikeresen felhasználható statisztikai, gazdasági elemzésekre és a módszer alkalmazható az üzleti gyakorlatban a szellemi tőke és a vállalatok üzleti teljesítménye közötti összefüggés vizsgálatára. Ez utóbbi két tényező egymásra gyakorolt hatásának egyre nagyobb jelentősége van nemcsak az IT szektorban, hanem a teljes szolgáltató szektor egészében. Mivel Magyarországra vonatkozóan hasonló számítás ez idáig még nem készült, éppen ezért munkánkat újszerű eredménynek tekintjük, mely további kutatási lehetőségek felvetését indukálja a kutatói társadalom számára.

\section{Irodalomjegyzék}

[1] Akhavan P. - Mehralian G. - Rasekh H. R. - Sadeh M. R. (2012): The Impact of Intellectual Capital Efficiency on Market Value: An Empirical Study from Iranian Pharmaceutical Companies. Iranian Journal of Pharmaceutical Research, Vol. 11, No. 1, pp. 195-207 
[2] Chen M. - Cheng S. - Yuchang H. (2005): An empirical investigation of the relationship between Intellectual capital and firms' market value and financial performance. Journal of Intellectual Capital, 6(2), pp. 159-176.

[3] Fenyves V. - Bács Z. - Droj L. - Tarnóczi T. (2018a): Significance and possibilities of measuring intellectual capital based on accounting statements. Economics \& Working Capital, 1-2., pp. 47-53.

[4] Fenyves V. - Bács Z. - Zéman Z. - Böcskei E. - Tarnóczi T. (2018b): The role of the notes to the financial statements in corporate decision-making. Corporate Ownership and Control 15:4, pp. 138-148

[5] Oláh J. - Popp J. - Erdei E. (2019): Az Ipar 5.0 megjelenése: ember és robot együttmúködése. Logisztikai trendek és legjobb gyakorlatok 5:1, pp. 12-19.

[6] Ousama, A. A. - And Fatima A. H (2015): Intellectual Capital and Financial Performance of Islamic Banks. International Journal of Learning and Intellectual Capital, Vol. 12, No. 1.

[7] Pulic, A. (1998), "Measuring the performance of intellectual potential in Knowledge economy", available at: http://www.measuring-ip.at/papers/Pulic. Letöltve:2019.02.04.

[8] Sabolovic, M (2009): Business Performance Analysis via VAICTM. European Research Studies, Vol. 12, No. 3.

[9] Śledzik, K. (2012): The Intellectual Capital Performance of Polish Banks: An

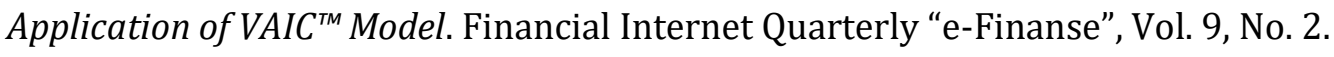

[10] Stahle, P. - Stahle S. - Aho, S. (2011): Value added intellectual coefficient (VAIC): a critical analysis. Journal of Intellectual Capital. Vol 12. No. 4, pp. 531-551.

[11] Svanadze, S. - Kowalewska, M. (2015): The measurement of intellectual capital by VAIC method - example of WIG20. Online Journal of Applied Knowledge Management, Volume 3, Issue 2.

[12] Sveiby K.E. - Lloyd, T. (1987): Managing KnowHow. London, Bloomsbury http://www.sveiby.com/articles/ManagingKnowHow.pdf Letöltve: 2019.10.15.

[13] Tarnóczi T. - Bács Z. - Böcskei E. - Fenyves V. (2017): Mérlegen (kívül) a tudásalapú gazdaság - az intellektuális tőke mérésének relevanciája. Controller Info 5:klsz. pp. 303-320.

[14] Trisnowati, Y. - Fadah, I (2014): The Impact of Intellectual Capital on Bank's Market Value and Financial Performance in Indonesia Stock Exchange. https://ssrn.com/abstract=2408325. Letöltve: 2019.10.14.

[15] Veltri S. - Silvestri A (2011): Direct and Indirect Effects of Human Capital on Firm Value: Evidence from Italian Companies. Journal of Human Resource Costing and Accounting, Vol. 15, No. 3, pp. 232-254 